\title{
IMPACT OF THE ESSENTIAL OILS OF MARJORAM OR BASIL DIETARY SUPPLEMENTATION ON DEGRADABILITY, RUMINAL FERMENTATION AND TOTAL GAS PRODUCTION IN-VITRO
}

\author{
Nadia A. H. Selim ${ }^{1}$, A. M. Abd El Tawab ${ }^{1}$, A. M. Kholif ${ }^{1}$, H. M. Elsayed ${ }^{2}$, N. E. El- \\ Bordeny $^{2}$ and Eman S.A. Farahat ${ }^{1}$ \\ ${ }^{1}$ Dairy Science Department, National Research Centre, 33 Buhouth St. Dokki, Giza, Egypt. \\ ${ }^{2}$ Animal Production Dept., Fac. of Agric., Ain-Shams Univ., 68 Hadayek Shoubra 11241, Cairo, \\ Egypt.
}

Corresponding Author: E-mail: amaeid2010@gmail.com /am.eid@nrc.sci.eg

(Received 2/2/2021, accepted 23/3/2021)

\section{SUMMARY}

\begin{abstract}
1 n in-vitro study was carried out to investigate the effect of using different levels of the essential oils of Marjoram (Origanum majorana L.) or Basil (Ocimum basilicum L.) as a natural feed additive on ruminal fermentation, total gas production, ammonia concentration, dry matter and cell wall contents (NDF and ADF) digestibility. Eleven experimental groups were used by invitro batch culture technique. The basal diet consisted of a total mixed ration (TMR) in all treatments, the experimental treatments were: 50\% CFM, 50\% alfalfa hay (control), control diet plus 5, 10, 15, 20 and $25 \mathrm{ml}$ of Marjoram oil or Basil oils / kg DM for T1, T2, T3, T4, T5, T6, T7, T8, T9 and T10, respectively. No differences $(p>0.05)$ were observed between Marjoram or Basil oils in $\mathrm{pH}$, NDFd and ADFd at all different levels compared with the control diet. Ammonia concentrations showed significant $(p<0.05)$ decreased for all the experimental diets compared with the control diet, except T6. Also, short chain fatty acid (SCFAs) contents were decreased for all treatments compared with control, except T8 and T9. The values cleared that Marjoram oils supplementation to diets showed a significant decrease $(p<0.05)$ in total gas production versus control which recorded the highest value $(128 \mathrm{ml})$ except T8 and T9. There was a significant increase $(p<0.05)$ in dry matter degradability (DMd) between T4 and T9 compared with the control. Cell wall contents (NDF and ADF) digestibility values were not significant affected by oils supplementations. It could be concluded that supplementation of Marjoram or Basil oils to diets had negative influence on ruminal fermentation parameters (SCFAs, ammonia and total gas production). The Marjoram oil showed significantly superior DM degradability and reduction total gas production compared to the Basil oil.
\end{abstract}

Keywords: Essential oils, Marjoram, Basil, digestibility, rumen fermentation and in-vitro.

\section{INTRODUCTION}

Recently, the main goals of livestock production system are minimizing the usage of synthetic and medicinal chemistry versus non-antibiotic growth promoters or natural growth promoters like plant extracts as modifiers of rumen fermentation process (Matloup et al., 2017; Khattab et al., 2019 and 2020a). Essential oils are commonly used as feed additives to animals as therapeutics and/or prophylactic to some metabolic disorders as well as, improve feed efficiency. Several studies were carried out to investigate plant secondary metabolites such as flavonoids, polysaccharides, coumarin, alkaloids, saponins and essential oils and their usage as natural ruminal modifiers (Knapp et al., 2014; Ishlak et al., 2015; Cobellis et al., 2016; Ali et al., 2016; Abd El Tawab et al., 2020 and 2021). Generally, the active components of essential oils revealed an antibacterial effect by deactivation of some microbial enzymes (El-Zaher et al., 2020). The antimicrobial properties of essential oils have been confirmed against a broad-spectrum of microorganisms such as bacteria, fungi and protozoa (Chao et al., 2000; Abd El Tawab et al., 2015 and 2019).

Many medical plants such as cinnamomum, rosemary, lemongrass, coriander, thyme, galangal and celery contained essential oils have been suggested on adjusting rumen fermentation and inhibition of deamination and methanogenesis, resulting in lower ammonia nitrogen, methane production and acetate, 


\section{Selim et al.}

and in higher propionate and butyrate concentrations also, decreased ruminal bio-hydrogenation (Matloup et al., 2017; Khattab et al., 2016; 2017; 2020a; Abd El Tawab et al., 2020 and 2021).

The essential oil of marjoram (Origanum majorana L.) contains thymol [(5-methyl-2-(1-methylethyl) phenol)], carvone, $\gamma$-terpinene, linalool and p-cymene depending on the origin and species of Origanum (Sivropoulou et al., 1996 and Baser, 2002). Thymol is a monoterpene with strong antimicrobial activity against a wide range of Gram positive and negative bacteria (Walsh et al., 2003 and Burt, 2004).

Basil (Ocimum basilicum L.) essential oil is determined based on the most common components (e.g. terpineol, linalool, limonene, methyl cinnamate, chavicol, eugenol and methyl eugenol) (Grayer et al., 1996). Eugenol (4-allyl-2-methoxyphenol) is a phenolic monoterpene that has antimicrobial activity against gram-positive and gram-negative bacteria (Dorman and Deans, 2000 and Walsh et al., 2003). Also, it has been able to reduce methane production or acetate, increase propionate production, and modify proteolysis, deamination or peptidolysis in the rumen (Calsamiglia, et al., 2007 and Abd El Tawab et al., 2021). Thus, the current study was aiming to investigate the effect of using different levels of Marjoram (Origanum majorana L.) or Basil (Ocimum basilicum L.) essential oils as a natural feed additive on ruminal fermentation, total gas production, ammonia nitrogen concentration, and dry matter, NDF and ADF degradability.

\section{MATERIALS AND METHODS}

\section{Experimental diets:}

In-vitro rumen fermentation technique incubation procedures were carried out as described by Abd El Tawab (2021). The basal diet consisted of a total mixed ration (TMR) in all treatments, the experimental treatments were: 50\% CFM : 50\% alfalfa hay (control), control diet plus $5 \mathrm{ml}$ Marjoram oil / kg DM (T1), control diet plus $10 \mathrm{ml}$ Marjoram oil / kg DM (T2), control diet plus $15 \mathrm{ml}$ Marjoram oil / kg DM (T3), control diet plus $20 \mathrm{ml}$ Marjoram oil / kg DM (T4), control diet plus $25 \mathrm{ml}$ Marjoram oil / kg DM (T5), control diet plus $5 \mathrm{ml}$ Basil oil / kg DM (T6), control diet plus $10 \mathrm{ml}$ Basil oil / kg DM (T7), control diet plus $15 \mathrm{ml}$ Basil oil / kg DM (T8), control diet plus $20 \mathrm{ml}$ Basil oil / kg DM (T9), control diet plus $25 \mathrm{ml}$ Basil oil / kg DM (T10). The chemical composition of CFM, alfalfa hay and experimental diets are presented in Table (1).

Table (1): Chemical composition of CFM, alfalfa hay and experimental diets (\% DM basis).

\begin{tabular}{llll}
\hline Item & CFM & Alfalfa hay & Experimental diets \\
\hline Dry matter & 91.27 & 92.60 & 91.94 \\
Organic matter & 95.67 & 93.90 & 94.79 \\
Crude protein & 14.90 & 17.50 & 16.20 \\
Ether extract & 5.30 & 2.90 & 4.10 \\
Non-fiber carbohydrate & 54.14 & 29.62 & 41.88 \\
Ash & 4.33 & 6.10 & 5.22 \\
Neutral detergent fiber & 21.33 & 43.88 & 32.61 \\
Acid detergent fiber & 6.32 & 32.66 & 19.49 \\
\hline
\end{tabular}

CFM: concentrate feed mixture; consisted of 57\% yellow corn, $25 \%$ wheat bran, $15 \%$ soybean meal, $0.6 \%$ sodium bicarbonate, $1 \%$ limestone, $0.8 \% \mathrm{NaCl}, 0.3 \%$ vitamins and $0.3 \%$ minerals.

\section{Samples analysis:}

After $24 \mathrm{~h}$ of incubation, gas production (GP), $\mathrm{pH}$ values and $\mathrm{NH} 3-\mathrm{N}$ concentration were analyzed according to Khattab and Abd El Tawab (2018). The amount of dry matter degradability (DMD) was determined according to AOAC (1995). Short chain fatty acids (SCFA) were calculated using the equation of Makkar (2005). Cell wall contents (NDF and ADF) were analyzed according to Van Soest et al. (1991). Gas production per gram DM, NDF and ADF were calculated according to Khattab et al. (2016).

\section{Statistical analysis procedures:}

Data were analyzed as a completely randomized design using GLM procedure of Statistical Analysis System (SAS, 2009), version 9.2. Significant differences between means of treatments were carried out by the Tukey's test, and the significance threshold was set at $\mathrm{p}<0.05$. The model was used.

$$
\mathrm{Yij}=\mu+\mathrm{Ti}+\mathrm{eij} \text {. }
$$


Where Yij is the parameter under analysis of the ij flask of laboratory trails, $\mu$ is the overall mean, $\mathrm{Ti}$ is the effect due to treatment on the parameter under analysis, eij is the experimental error for ij on the observation,

\section{RESULTS AND DISCUSSION}

\section{Ruminal fermentation:}

Data in Table (2) showed that the effect of Marjoram or Basil oils supplementation to diets on ruminal fermentation parameters. Generally, no differences $(p>0.05)$ were observed between Marjoram or Basil oils in $\mathrm{pH}$ values at all different levels compared with control. While, there was insignificant $(P>0.05)$ increased between treatments at high levels of Marjoram or Basil oils and control. $\mathrm{pH}$ values are an important index for investigating the inclusive essential oils impact on the microbial population and ruminal fermentation and subsequently the ruminal environment (Kumar et al., 2013). The results in the present study affirmed the results from previous studies that found oregano (essential oil $1.4 \%$ or $1.58 \%$ of oregano leaf on DM) supplementation to lactating dairy cows' diets had no significant effect on rumen pH (Tekippe et al., 2011 and Hristov et al., 2013). Also, Evans and Martin (2000) found that ruminal pH was not affected at a lower dose of thyme oil $(50,100,200 \mathrm{mg} / \mathrm{L})$ while, it was increased at $400 \mathrm{mg} / \mathrm{L}$ (in vitro). The increase in $\mathrm{pH}$ at high level of thyme oils could be related to the high levels of thymol which had a strong effect of rumen microbial fermentation and contribute to a reduction in methane, propionate, acetate and lactate concentrations. Castillejos et al. (2006) reported similar results after using different levels of various essential oils that contained some active components such as thymol, eugenol, limonene, guaiacol, $Y$-terpinene and vanillin and contributed to increased ruminal $\mathrm{pH}$ value reduced in ruminal fermentation and depression in TVFAs concentration. Moreover, Benchaar et al. (2007) reported an increase in the $\mathrm{pH}$ values with the supplementation of $400,200,400,800 \mathrm{mg} / \mathrm{L}$ of cinnamon, thymol, carvacrol and eugenol respectively. Also, Busquet et al. (2006) suggested that the addition of $3 \mathrm{~g} / \mathrm{L}$ of eugenol and 0.3 and $3 \mathrm{mg} / \mathrm{L}$ of carvacrol contributed to the $\mathrm{pH}$ increase. Patra and $\mathrm{Yu}$ (2012) found a linear increase $\mathrm{pH}$ values when eucalyptus, clove, garlic, peppermint and origanum oils were added in doses of $0.10,0.25$, and $1 \mathrm{~g} / \mathrm{L}$. Kouazounde et al. (2015) found that the addition of essential oils from African basil (Ocimum gratissimum) to diets has increased the $\mathrm{pH}$ values of rumen fermenter liquid in the rumen simulation technique (RUSITEC).

Table (2): Effect of supplementing diet with different levels of marjoram or basil oils on some ruminal fermentation parameters.

\begin{tabular}{|c|c|c|c|c|c|c|c|c|c|c|c|c|c|}
\hline \multirow[t]{2}{*}{ Item } & \multirow[t]{2}{*}{ Control } & \multicolumn{5}{|c|}{ Marjoram oil } & \multicolumn{5}{|c|}{ Basil oil } & \multirow[t]{2}{*}{ SEM } & \multirow{2}{*}{$\begin{array}{c}P \\
\text { value }\end{array}$} \\
\hline & & $\mathrm{T} 1$ & $\mathrm{~T} 2$ & T3 & $\mathrm{T} 4$ & T5 & T6 & $\mathrm{T} 7$ & T8 & T9 & $\mathrm{T} 10$ & & \\
\hline $\mathrm{pH}$ & 6.75 & 6.74 & 6.84 & 6.82 & 6.84 & 6.85 & 6.76 & 6.78 & 6.81 & 6.84 & 6.85 & 0.028 & 0.099 \\
\hline $\begin{array}{l}\text { Ammonia } \\
(\mathrm{mg} / \mathrm{dl})\end{array}$ & $35.5^{\mathrm{a}}$ & $30.7^{\mathrm{bc}}$ & $27.5^{\mathrm{cd}}$ & $26.7^{\mathrm{cd}}$ & $25.7^{\mathrm{d}}$ & $30.7^{\mathrm{bc}}$ & $32.6^{\mathrm{ab}}$ & $29.7^{\mathrm{bcd}}$ & $27.8^{\mathrm{cd}}$ & $25.6^{\mathrm{d}}$ & $25.8^{\mathrm{d}}$ & 0.582 & $<.0001$ \\
\hline $\begin{array}{l}\text { SCFA } \\
(\mathrm{mmol})\end{array}$ & $1.42^{\mathrm{a}}$ & $1.25^{\mathrm{c}}$ & $1.28^{\mathrm{bc}}$ & $1.27^{\mathrm{bc}}$ & $1.32^{\mathrm{bc}}$ & $1.28^{\mathrm{bc}}$ & $1.29^{\mathrm{bc}}$ & $1.32^{\mathrm{bc}}$ & $1.35^{\mathrm{ab}}$ & $1.34^{\mathrm{abc}}$ & $1.31^{\mathrm{bc}}$ & 0.0088 & $<.0001$ \\
\hline
\end{tabular}

Control: 50\% CFM, 50\% alfalfa hay,T1: control diet $+5 \mathrm{ml}$ Marjoram oil / $\mathrm{kg} \mathrm{DM}, \mathrm{T2}$ : control diet $+10 \mathrm{ml}$ Marjoram oil / kg DM, T3: control diet $+15 \mathrm{ml}$ Marjoram oil / $\mathrm{kg}$ DM,T4: control diet $+20 \mathrm{ml}$ Marjoram oil / $\mathrm{kg}$ DM, T5: control diet $+25 \mathrm{ml}$ Marjoram oil / $\mathrm{kg} D \mathrm{DM}$, T6: control diet $+5 \mathrm{ml}$ Basil oil / $\mathrm{kg}$ DM, T7: control diet +10 $\mathrm{ml}$ Basil oil / kg DM, T8: control diet + $15 \mathrm{ml}$ Basil oil / kg DM, T9: control diet + $20 \mathrm{ml}$ Basil oil / kg DM, T10: control diet $+25 \mathrm{ml}$ Basil oil / $\mathrm{kg} D M$.

SCFA; short chain fatty acids.

Different superscripts $a, b, c$ and $d$ at the same row differ significantly $(p<0.05)$.

SEM: standard error of the means.

Ammonia concentrations showed significant $(\mathrm{p}<0.05)$ decreased for all the experimental diets compared with the control diet, except T6. the chemical components of essential oils had a variable impact on ruminal nitrogen metabolism in different studies. A decreased in ammonia- $\mathrm{N}$ concentration is suggesting the potentiality of Marjoram or Basil oils for inhibiting deamination. These results were consistent with McIntosh et al. (2000) who noted that essential oils during an in-vitro study prevented deamination of amino acids in the rumen measured by $25 \%$, these potential related to inhibiting rumen microbe's attachment to feed particles (Wallace et al., 2002). Also, Castillejos et al. (2005) reported that the microorganism's species and population were greatly affected by essential oils as the same of those in 


\section{Selim et al.}

antibiotics. They also reported that essential oils had inhibited hyper-ammonia producing (HAP) bacteria such as Peptostreptecoccus anaerobius and Clostridium sticklandii associated with a reduction of ammonia production, while the other hyper-ammonia producing species such as Clostridium aminophilum was less sensitive affected (McEwan et al., 2002 and McIntosh et al., 2003).

Hyper-ammonia producing bacteria are present in low numbers in the rumen fluid (less than 0.01 of the rumen bacterial population) but, it has a very high deamination activity (Russell et al., 1988). Collectively, results of the studies by McIntosh et al. (2003), Wallace (2004) and Newbold et al. (2004) reported that essential oils produced an inhibitory influence on Hyper-ammonia producing bacteria contributing to lowered ruminal protein metabolism and amino acids degradation (deamination). Differences in the effects of essential oils supplementation to diets on NH3-N between in vivo or in vitro studies could be adequate in part by the capability of rumen microbial populations to degrade and / or adapt essential oils components. (Benchaar and Greathead, 2011). Busquet et al. (2006) found that the carvacrol when added a dose of $3 \mathrm{~g} / \mathrm{L}$ decreased the concentration of ammonia nitrogen during in-vitro batch cultures.

Short chain fatty acid (SCFAs) contents were significantly decreased for all treatments compared with control, except T8 and T9, the control recorded the highest value (1.42 mmol). Reduction of SCFAs in Marjoram or Basil oils treatment could be a great index of simultaneous with methane reduction in the rumen tract (Busquet et al., 2006). The change in molar proportions of TVFs led to a lack of a change TVFs concentration, decreased methane production and decreased NH3-N concentration. However, essential oils supplementation to diets leads to a reduction in TVFAs production and was viewed as nutritionally unfavorable (Khattab et al., 2020a). Kouazounde et al. (2015) found that TVFAs production was linearly decreased by African basil (Ocimum gratissimum) essential oils supplementation to diets with a shift in VFAs profile towards more acetate and butyrate and less propionate. While, other studies revealed that certain essential oils and their components have the same manner as the antibiotics to shift molar proportions of VFAs (i.e. increased propionate and decreased acetate proportions) (McGuffey et al., 2001). Also, Mohammed et al. (2004) found increased propionate and decreased acetate proportions with encapsulated cyclodextrin horseradish in both in-vivo and in-vitro studies. The SCFAs concentration and the proportion of propionate to acetate were decreased, while acetate to propionate ratio was increased when thymol (0.4 g/L) was used (Evans and Martin, 2000). Also, Castillejos et al. (2006) suggested the similar results for limonene, thymol, guaiacol and eugenol components using doses of more than 5g/L. Moreover, Kamalak et al. (2011) reported that thymol supplementation up to $0.2 \mathrm{~g} / \mathrm{L}$ had no significant effect on molar propionate, acetate or butyrate proportions.

\section{Gas Production:}

In-vitro rumen gas production measurements of experimental treatments supplemented with different levels of Marjoram or Basil oils are illustrated in Table (3). The values cleared that Marjoram oils supplementation to diets showed a significant decrease $(p<0.05)$ in total gas production (TGP) compared with control treatment which, recorded the highest value $(128 \mathrm{ml})$ while, it was insignificantly increased $(P>0.05)$ versus T8 and T9 treatments $(122$ and $121 \mathrm{ml})$, respectively. Also, the current results revealed that gas production per each gram of NDF recorded the same trend of total gas production (Table 3 ). Gas production per each gram of DM and ADF showed a significant decrease $(P<0.05)$ in essential oils treatments compared with control treatment (346 and $1763 \mathrm{ml}$, respectively) while, it was insignificantly increased $(p>0.05)$ versus T7, T8 and T9 treatments. Supplementation of essential oils have caused positively affect gas production and modified rumen fermentation in various in-vitro in-vivo studies (Macheboeuf et al., 2008; Patra and Yu, 2012; Lin et al., 2012; Cobellis et al., 2016 and Khattab et al., 2020a). These findings were synchronized with Benchaar et al. (2007) who recorded a reduction in gas emission when several types of essential oils such as thymol $(0.2 \mathrm{~g} / \mathrm{L})$, carvacrol $(0.4 \mathrm{~g} / \mathrm{L})$ and eugenol $(0.8 \mathrm{~g} / \mathrm{L})$ were tested with an in-vitro batch fermentation system. Also, Kouazounde et al. (2015) reported that the addition of essential oils from African basil (Ocimum gratissimum) to diets decreased the total gas production and methane emission in the rumen simulation technique (RUSITEC). Oh et al. (1967) suggested an inhibition of rumen microbial activity based on the decrease in total gas production when a $0.12 \mathrm{ml} / \mathrm{L}$ dose of terpenoid essential oils from Douglas-fir needles leaves (limonene, $\alpha$-pinene, myrcene, $\beta$-pinene, terpinolene, A3-carene, and cz amphene) was used an in-vitro study. Rezaei and Pour (2012) noted that the total gas production was decreased with the addition of thyme methanolic extracts. Also, Chaudhry and Khan (2012) found that by using an in-vitro gas production technique, five curry spices such as cumin, turmeric, coriander, cinnamon and clove as act a non-antibiotic growth promoter and contribute to killing methanogenic bacteria which lead to a reduction of methane emission by $40 \%$. Nagy and Tengerdy (1968) suggested that essential oils extracted from Sagebrush (Artemesia tridentata) markedly caused inhibition of rumen bacterial activity as gas production during in vitro study. Moreover, the degree of inhibition depended on the chemical composition of the essential oils compound added. 
These compounds are divided into particularly monoterpene alcohols, aldehydes and oxygenated monoterpenes, that strongly inhibited the metabolism and growth of rumen microbes. Whereas, monoterpene hydrocarbons stimulated or slightly inhibited the activity of rumen microbes (Benchaar et al., 2008). Kim et al. (2012) evaluated that the herbal plant extracts (Mandarin orange, Lonicera japonica; Honeysuckle; Artemisia princeps var. Orientalis; Garlic, Allium cepa; Ginger, Citrus unshiu; Onion, Zingiber officinale; Wormwood, Allium sativum for. Pekinense) were shown to have properties to decrease methanogens bacteria, methane production and acetate to propionate ratios and increase fibrolytic bacteria species. It is well-known that the cell wall contents ADF were negatively correlated with gas production which tends to reduce the microbial activity (Khattab and Abd EL Tawab, 2018).

Table (3): Effect of supplementing diet with different levels of marjoram or basil oils on ruminal gas production $(\mathrm{ml})$.

\begin{tabular}{|c|c|c|c|c|c|c|c|c|c|c|c|c|c|}
\hline \multirow[t]{2}{*}{ Item } & \multirow[t]{2}{*}{ Control } & \multicolumn{5}{|c|}{ Marjoram oil } & \multicolumn{5}{|c|}{ Basil oil } & \multirow[t]{2}{*}{ SEM } & \multirow{2}{*}{$\begin{array}{c}P \\
\text { value }\end{array}$} \\
\hline & & T1 & $\mathrm{T} 2$ & $\mathrm{~T} 3$ & $\mathrm{~T} 4$ & T5 & T6 & $\mathrm{T} 7$ & T8 & T9 & T10 & & \\
\hline TGP & $128^{\mathrm{a}}$ & $113^{\mathrm{c}}$ & $116^{\mathrm{bc}}$ & $115^{\mathrm{bc}}$ & $119^{b c}$ & $116^{\mathrm{bc}}$ & $116^{\mathrm{bc}}$ & $120^{\mathrm{bc}}$ & $122^{\mathrm{ab}}$ & $121^{\mathrm{abc}}$ & $118^{\mathrm{bc}}$ & 0.810 & 0.0001 \\
\hline $\begin{array}{c}\text { GP/gram } \\
\text { DM }\end{array}$ & $346^{\mathrm{a}}$ & $305^{\mathrm{b}}$ & $312^{\mathrm{b}}$ & $307^{\mathrm{b}}$ & $319^{\mathrm{b}}$ & $314^{\mathrm{b}}$ & $314^{\mathrm{b}}$ & $322^{\mathrm{ab}}$ & $329^{\mathrm{ab}}$ & $326^{\mathrm{ab}}$ & $319^{\mathrm{b}}$ & 2.266 & 0.0003 \\
\hline $\begin{array}{c}\text { GP/gram } \\
\text { NDF }\end{array}$ & $1057^{\mathrm{a}}$ & $934^{\mathrm{b}}$ & $950^{\mathrm{b}}$ & $952^{\mathrm{b}}$ & $981^{\mathrm{b}}$ & $959^{\mathrm{b}}$ & $960^{\mathrm{b}}$ & $985^{\mathrm{b}}$ & $1005^{\mathrm{ab}}$ & $995^{\mathrm{ab}}$ & $977^{\mathrm{b}}$ & 6.694 & 0.0003 \\
\hline $\begin{array}{c}\text { GP/gram } \\
\text { ADF }\end{array}$ & $1763^{\mathrm{a}}$ & $1561^{\mathrm{b}}$ & $1586^{\mathrm{b}}$ & $1591^{\mathrm{b}}$ & $1637^{\mathrm{b}}$ & $1602^{b}$ & $1604^{b}$ & $1644^{\mathrm{ab}}$ & $1677^{\mathrm{ab}}$ & $1660^{\mathrm{ab}}$ & $1631^{\mathrm{b}}$ & 11.054 & 0.0005 \\
\hline
\end{tabular}

Control: 50\% CFM, 50\% alfalfa hay,T1: control diet $+5 \mathrm{ml}$ Marjoram oil / $\mathrm{kg} \mathrm{DM}, \mathrm{T2}:$ control diet $+10 \mathrm{ml}$ Marjoram oil / kg DM, T3: control diet $+15 \mathrm{ml}$ Marjoram oil / kg DM,T4: control diet $+20 \mathrm{ml}$ Marjoram oil / kg DM, T5: control diet $+25 \mathrm{ml}$ Marjoram oil / $\mathrm{kg}$ DM, T6: control diet $+5 \mathrm{ml} \mathrm{Basil} \mathrm{oil} \mathrm{/} \mathrm{kg} \mathrm{DM,} \mathrm{T7:} \mathrm{control} \mathrm{diet}+10$ $\mathrm{ml}$ Basil oil / kg DM, T8: control diet $+15 \mathrm{ml}$ Basil oil / kg DM, T9: control diet + $20 \mathrm{ml}$ Basil oil / kg DM, T10: control diet $+25 \mathrm{ml}$ Basil oil / $\mathrm{kg} D M$.

Total GP; total gas production after 24hours.

Different superscripts $a, b, c$ and $d$ at the same row differ significantly $(p<0.05)$.

SEM: standard error of the means.

\section{Nutrients degradability:}

In-vitro nutrients degradability is presented in Table (4) revealed a significant increase $(P<0.05)$ in

Table (4): Effect of supplementing diet with different levels of marjoram or basil oils on ruminal nutrients degradability $(\%)$.

\begin{tabular}{|c|c|c|c|c|c|c|c|c|c|c|c|c|c|}
\hline \multirow{2}{*}{ Item } & \multirow{2}{*}{ control } & \multicolumn{5}{|c|}{ Marjoram oil } & \multicolumn{5}{|c|}{ Basil oil } & \multirow{2}{*}{$S E M$} & \multirow{2}{*}{$\begin{array}{c}P \\
\text { value }\end{array}$} \\
\hline & & $\mathrm{T} 1$ & $\mathrm{~T} 2$ & $\mathrm{~T} 3$ & $\mathrm{~T} 4$ & $\mathrm{~T} 5$ & T6 & $\mathrm{T} 7$ & $\mathrm{~T} 8$ & T9 & $\mathrm{T} 10$ & & \\
\hline DMd & $37.6^{c}$ & $38.5^{\mathrm{c}}$ & $39.9^{\mathrm{abc}}$ & $39.2^{\mathrm{bc}}$ & $44.0^{\mathrm{a}}$ & $40.1^{\mathrm{abc}}$ & $40.1^{\mathrm{abc}}$ & $40.5^{\mathrm{abc}}$ & $40.8^{\mathrm{abc}}$ & $43.9^{\mathrm{ab}}$ & $41.4^{\mathrm{abc}}$ & 0.411 & 0.0014 \\
\hline NDFd & 36.1 & 35.5 & 36.3 & 36.4 & 36.6 & 35.0 & 35.0 & 36.5 & 34.8 & 35.2 & 34.2 & 0.454 & 0.9902 \\
\hline ADFd & 31.7 & 27.4 & 29.1 & 31.5 & 32.1 & 28.0 & 28.8 & 27.2 & 26.6 & 26.0 & 31.5 & 0.569 & 0.1296 \\
\hline
\end{tabular}

Control: 50\% CFM, 50\% alfalfa hay,T1: control diet $+5 \mathrm{ml}$ Marjoram oil / $\mathrm{kg} \mathrm{DM,} \mathrm{T2:} \mathrm{control} \mathrm{diet}+10 \mathrm{ml}$ Marjoram oil / kg DM, T3: control diet $+15 \mathrm{ml}$ Marjoram oil / kg DM,T4: control diet + $20 \mathrm{ml}$ Marjoram oil / $\mathrm{kg}$ DM, T5: control diet $+25 \mathrm{ml}$ Marjoram oil / $\mathrm{kg}$ DM, T6: control diet $+5 \mathrm{ml}$ Basil oil / $\mathrm{kg} \mathrm{DM,} \mathrm{T7:} \mathrm{control} \mathrm{diet}+10$ $\mathrm{ml}$ Basil oil / kg DM, T8: control diet + $15 \mathrm{ml}$ Basil oil / kg DM, T9: control diet + $20 \mathrm{ml}$ Basil oil / kg DM, T10: control diet $+25 \mathrm{ml}$ Basil oil / $\mathrm{kg}$ DM.

DMd: dry matter disappearance; NDFd: natural detergent fiber disappearance; ADFd: acid detergent fiber disappearance.

Different superscripts $a, b, c$ and $d$ at the same row differ significantly $(p<0.05)$.

SEM: standard error of the means.

dry matter degradability (DMd) between T4 and T9 being (44 and 43.9\%, respectively) compared with control and T1 which recorded the lowest values being (37.6 and 38.5\%, respectively). The enhanced dry matter digestibility with the addition of Marjoram or Basil oils confirmed the beneficial effect of their active components. It seems credible to indicate that the concentrations of active components in 


\section{Selim et al.}

Marjoram or Basil oils were below the sill levels at which nutrient digestion is inhibited (Khattab et al., 2016; 2017; 2020a and 2020 b). The essential oils contain several secondary metabolites and hydrocarbons (e.g., Terpineol, linalool, Limonene, methyl cinnamate, thymol and limonene), with different dose-dependent antimicrobial activities against some ruminal protozoa and bacteria species (Benchaar et al., 2008). The improved digestion confirmed that the dose of Marjoram or Basil oils were lower than that dose which destroys the activities of ruminal microorganisms (Walsh et al., 2003). These results were in agreements with Khattab et al. (2020b) who found that the dry matter digestibility increased by thyme supplementation to ewes' diets $(20 \mathrm{~g} / \mathrm{h} / \mathrm{d})$.

While, cell wall contents degradability (NDFd and ADFd) results appeared non-significant $(p>0.05)$ variances between control and other treatments. These findings were in agreement with Patra (2011) who found the essential oils have no negative effect on fiber degradation (NDFd and ADFd). Also, Khattab et al. (2020a) showed the similar results when they used celery and thyme in an in vitro study. Kali (2017) found that NDFd and ADFd were not affected by experimental treatment when used a pellet containing Stay Strong (a commercially available blend of essential oils) in lactating dairy cows. Also, Castillejos et al. (2006) suggested no negative effect on activity and growth of the major cellulolytic bacterial population by adding $0.005,0.05$, and $0.5 \mathrm{~g} / \mathrm{L}$ of eugenol in a continuous-culture fermenter, and reported no effects on NDF, and ADF digestibility.

\section{CONCLUSION}

Based on the conditions of the present in-vitro study. It could be concluded that supplementation of Marjoram or Basil oils (a natural feed additive) to diets contributed to a negative influence on ruminal fermentation parameters (SCFAs, ammonia-N and total gas production), while dry matter degradability was increased at level $20 \mathrm{ml} / \mathrm{kg}$ DM. The Marjoram oil showed superior DM degradability and reduction in total gas production compared to the Basil oil. Recently, the in-vivo study is carrying out to investigate more topics such as the effect of those essential oils (Marjoram or Basil) on the lactational performance of dairy goats.

\section{ACKNOWLEDGEMENT}

Authors are thankful to the all-staff members of my Laboratory, Department and Centre for providing research a facility and conducive environment for the current research study.

\section{REFERENCES}

Abd El Tawab, A.M., M.S.A. Khattab, F.I. Hadhoud and M.M. Shaaban (2021). Effect of mixture of herbal plants on ruminal fermentation, degradability and gas production. Acta Scientiarum. Animal Sciences, 43(1): e48549. doi.org/10.4025/actascianimsci.v43i1.48549.

Abd El Tawab, A.M., A.E. Kholif, M.S.A. Khattab, M.M. Shaaban, F.I. Hadhoud, M.M.M. Mostafa and O.A. Olafadehan (2020). Feed utilization and lactational performance of Barki sheep fed diets containing thyme or celery. Small Ruminant Research, 192:106249. https://doi.org/10.1016/j.smallrumres.2020.106249.

Abd El Tawab, A.M., H.A. Murad, M.S.A. Khattab and H.H. Azzaz (2019). Optimizing Production of Tannase and in vitro Evaluation on Ruminal Fermentation, Degradability and Gas Production. International Journal of Dairy Science, 14: 53-60.

Abd El Tawab, A.M., O.H. Matloup, A.M. Kholif, S.A.H. Abo El-Nor, H.A. Murad, H.M., El-Sayed and M.M. Khorshed (2015). Influence of addition of tannase enzyme to reducing tannins effects in lactating goats diets. International Journal of Dairy Science, 10(1): 24-35.

Ali, S.I., A.A. Mohamed, M.Y. Sameeh, O.M. Darwesh and T.M. Abd El-Razik (2016). Gammairradiation affects volatile oil constituents, fatty acid composition and antimicrobial activity of Fennel (Foeniculum vulgare) seeds extract. Res. J. Pharm. Biol. Chem. Sci., 7 (1):524-532.

AOAC (1995) Official Methods of Analysis. 16th Edition, Association of Official Analytical Chemists, Washington DC, USA. 
Baser, K.H.C. (2002). The Turkish Origanum species. Pages 109-126 in Oregano: The Genera Origanum and Lippia, S. E. Kintzios, ed. Taylor and Francis, London, UK and New York, NY.

Benchaar, C. and H. Greathead (2011). Essential oils and opportunities to mitigate enteric methane emissions from ruminants. Anim. Feed. Sci. Technol., 166-167:338-355.

Benchaar, C., H.V. Petit, R. Berthiaume, D.R. Ouellet, J. Chiquette and P.Y. Chouinard (2007). Effects of essential oils on digestion, ruminal fermentation, rumen microbial populations, milk production, and milk composition in dairy cows fed alfalfa silage or corn silage. J. Dairy Sci., 90: 886-897.

Benchaar, C., S. Calsamiglia, A.V. V. Chaves, G.R.R. Fraser, D. Colombatto, T.A.A. McAllister, K.A.A. Beauchemin, D. Colombatto, T.A.A. McAllister and K.A.A. Beauchemin (2008). A review of plantderived essential oils in ruminant nutrition and production. Anim. Feed Sci. Technol., 145: 209-228. https://doi.org/10.1016/j.anifeedsci.2007.04.014.

Burt, S. (2004). Essential oils: their antimicrobial properties and potential applications in foods: a review. Int. J. Food Microbiol., 94:223-253. doi: 10.1016/j.ijfoodmicro.2004.03.022.

Busquet, M, S. Calsamiglia, A. Ferret and C. Kamel (2006). Plant extracts affect in vitro rumen microbial fermentation. J. Dairy Sci., 89(2):761-771.

Calsamiglia, S., M. Busquet, P.W. Cardozo, L. Castillejos and A. Ferret (2007). Invited review: Essential oils as modifiers of rumen microbial fermentation. J. Dairy Sci., 90:2580-2595.

Castillejos, L., S. Calsamiglia and A. Ferret (2006). Effect of essential oils active compounds on rumen microbial fermentation and nutrient flow in in vitro systems. J. Dairy Sci., 89:2649-2658.

Castillejos, L., S. Calsamiglia, A. Ferret and R. Losa (2005). Effects of a specific blend of essential oil compounds and the type of diet on rumen microbial fermentation and nutrient flow from a continuous culture system. Anim. Feed Sci. Technol., 119:29-41.

Chao, S.C., D.G. Young and C.J. Oberg (2000). Screening for inhibitory activity of essential oils on selected bacteria, fungi and viruses. J. Essent. Oil Res., 12:639-649.

Chaudhry, A.S. and M.M.H. Khan (2012). Impacts of different spices on in vitro rumen dry matter disappearance, fermentation and methane of wheat or ryegrass hay based substrates. Livestock Science, 146, 84-90.

Cobellis, G., M. Trabalza-Marinucci, M.C. Marcotullio and Z. Yu (2016). Evaluation of different essential oils in modulating methane and ammonia production, rumen fermentation, and rumen bacteria in vitro. Animal Feed Science and Technology, 215: 25-36.

Dorman, H.J.D. and S.G. Deans (2000). Antimicrobial agents from plants: antibacterial activity of plant volatile oils.J. Appl. Microbiol., 88: 308-316.

El-Zaher, H.M., S.Y. Eid, M.M. Shaaban, O.A. Ahmed-Farid, A.M. Abd El Tawab and M.S.A. Khattab (2020). Ovarian activity and antioxidant indices during estrous cycle of Barki ewes under effect of thyme, celery and salinomycin as feed additives. Zygote, 1-6. doi:10.1017/S096719942000061.

Evans, J.D. and S.A. Martin (2000). Effects of thymol on ruminal microorganisms. Curr. Microbio., 1 41:336-340.

Grayer, R.J., G.C. Kite, F.J. Goldstone, S.E. Bryan, A. Paton and E. Putievsky (1996). Intraspecific taxonomy and essential oil chemotypes in Sweet basil, Ocimum basilicum. Phytochemistry, 43(5): 1033-1039.

Hristov, A.N., C. Lee, T. Cassidy, K. Heyler, J.A. Tekippe and G.A. Varga (2013). Effect of Origanum Vulgare L. leaves on rumen fermentation, production, and milk fatty acid composition in lactating dairy cows. J Dairy Sci., 96:1189-1202. https://doi.org/10.3168/jds.2012-5975 PMID: 23245964.

Ishlak, A., M. Gunal and A.A. AbuGhazaleh (2015). The effects of cinnamaldehyde, monensin and quebracho condensed tannin on rumen fermentation, biohydrogenation and bacteria in continuous culture system. Anim. F. Sci. Technol., 207:31- 40.

Kali, L. (2017). The Effects of a Blend of Essential Oils on Rumen Efficiency of Lactating Dairy Cows. Electronic Theses and Dissertations. 1230. https://openprairie.sdstate.edu/etd/1230.

Kamalak, A., A.I. Atalay, C.O. Ozkon, A. Tatliyer and E. Kaya (2011). Effect of essential orange (Citrus sinensis L.) oil on rumen microbial fermentation using in vitro gas production technique. J. Anim. Plant Sci., 21: 764-769.

Khattab, M.S.A. and A.M. Abd El Tawab (2018). In vitro evaluation of palm fronds as feedstuff on ruminal digestibility and gas production. Acta Scientiarum Animal Sciences. v. 40, e39586.

Khattab, M.S.A., H.M. Ebeid, A.M. Abd El Tawab, S.A.H. Abo El-Nor and A.A. Aboamer (2016). Effect of supplementing diet with herbal plants on ruminal fiber digestibility and gas production. Res. J. of Pharm., Bio. Chem. Sci., 7(6):1093-1097.

Khattab, M.S.A., H.M. El-Zaiat, A.M. Abd El Tawab, O.H. Matloup, A.S. Morsy, M.M. Abdou, H.M. Ebeid, M.F.A. Attia and S.M.A. Sallam (2017). Impact of lemongrass and galangal as feed additives on performance of lactating Barki goats. Int. J. Dairy Sci., 12: 184-189. 


\section{Selim et al.}

Khattab, M.S.A., H.H. Azzaz, A.M. Abd El Tawab and H.A. Murad (2019). Production Optimization of Fungal Cellulase and its Impact on Ruminal Degradability and Fermentation of Diet. International Journal of Dairy Science, 14: 61-68. DOI: 10.3923/ijds.2019.61.68.

Khattab, M.S.A., A.M. Abd El Tawab, F.I. Hadhoud and M.M. Shaaban (2020a). Utilizing of Celery and Thyme as Ruminal Fermentation and Digestibility Modifier and Reducing Gas Production. International Journal of Dairy Science, 15: 22-27.

Khattab, M.S.A., A.E. Kholif, A.M. Abd El Tawab, M.M. Shaaban, F.I. Hadhoud, H.A. El-Fouly and O.A. Olafadehan (2020b). Effect of replacement of antibiotics with thyme and celery seed mixture on the feed intake and digestion, ruminal fermentation, blood chemistry, and milk lactation of lactating Barki ewes. Food \& Function, 11, 6889-6898. DOI: 10.1039/d0fo00807a.

Kim, S.C., A.T. Adesogan and J.H. Shin (2012). Effects of dietary addition of wormwood (Artemisia montana Pampan) silage on growth performance, carcass characteristics, and muscle fatty acid profiles of beef cattle. Animal Feed Science and Technology, 177:15-22.

Knapp J.R., Laur G.L., Vadas P.A., Weiss W.P., Tricarico J.M. (2014). Invited review: Enteric methane in dairy cattle production: Quantifying the opportunities and impact of reducing emissions. J. Dairy Sci., 97:3231-3261.

Kouazounde, J.B., J.D. Gbenou, M. He, T. Jardim, L. Jin, Y. Wang, K.A. Beauchemin and T.A. McAllister (2015). Effects of essential oils from African basil on fermentation of Andropogon gayanus grass in the Artificial Rumen (RUSITEC). Can. J. Anim. Sci., 95: 425-431.

Kumar, S., S.S. Dagar, S.K. Sirohi, R.C. Upadhyay and A.K. Puniya (2013). Microbial profiles, in vitro gas production and dry matter digestibility based on various ratios of roughage to concentrate. Ann Microbiol., 63: 541-545.

Lin, B., Y. Lu, J.H. Wang, Q. Liang and J.X.J. Liu (2012). The effects of combined essential oils along with fumarate on rumen fermentation and methane production in vitro. Anim. Feed Sci., 21:198-210.

Macheboeuf, D., D.P. Morgavi, Y. Papon, J.L. Mousset and M. Arturo-Schaan (2008). Dose-response effects of essential oils on In vitro fermentation activity of the rumen microbial population. Anim. Feed Sci. Technol., 145: 335-350.

Makkar, H.P.S. (2005). In-vitro gas methods for evaluation of feeds containing phytochemicals. Anim. Feed Sci. Technol., 123: 291-302.

Matloup, O.H., A.M. Abd El Tawab, A.A. Hassan, F.I. Hadhoud, M.S.A. Khattab, M.S. Khalel, S.M.A. Sallam and A.E. Kholif (2017). Performance of lactating Friesian cows fed a diet supplemented with coriander oil: Feed intake, nutrient digestibility, ruminal fermentation, blood chemistry and milk production. Anim. Feed Sci. Technol., 226: 88-97.

McEwan, N.R., R.C. Graham, R.J. Wallace, R. Losa, P. Williams and C.J. Newbold (2002). Effect of essential oils on ammonia production by rumen microbes. Reprod. Nutr. Dev. 42(Suppl.1): S65. (Abstr.).

McGuffey, R.K., L.F. Richardson and J.I.D. Wilkinson (2001). Ionophores for dairy cattle: Current status and future outlook. J. Dairy Sci., 84 (E. Suppl.), E194-E203.

McIntosh, F.M., C.J. Newbold, R. Losa, P. Williams and R.J. Wallace (2000). Effects of Essential Oil on Rumen Fermentation. Reprod. Nurt. Dev. 40 (Suppl.2): 221-222 (Abstract).

McIntosh, F.M., P. Williams, R. Losa, R.J. Wallace, D.A. Beever and C.J. Newbold (2003). Effects of Essential Oils on Ruminant Microorganisms and Their Protein Metabolism. App. Environ. Microbiol., 69:5011-5014.

Mohammed, N., N. Ajisaka, Z.A. Lila, K. Mikuni, K. Hara, S. Kanda and H. Itabashi (2004). Effect of Japanese horseradish oil on methane production and ruminal fermentation in vitro and in steers. J. Anim. Sci., 82:1839-1846.

Nagy, J.G. and R.P. Tengerdy (1968). Antibacterial action of essential oils of Artemisia as an ecological factor. II. Antibacterial action of the volatile oils of Artemisia tridentata (big sagebrush) on bacteria from the rumen of mule deer. Appl. Microbiol., 16:441-444.

Newbold, C.J., F.M. McIntosh, P. Williams, R. Losa and R.J. Wallace (2004). Effects of a specific blend of essential oil compounds on rumen fermentation. Anim. Feed Sci. Technol., 114: 105-112.

Oh, H.K., T. Sakai, M.B. Jones and W.M. Longhurst (1967). Effect of various essential oils isolated from Douglas fir needles upon sheep and deer rumen microbial activity. Appl. Microbiol., 15:777-784.

Patra, A.K. (2011). Effects of essential oils on rumen fermentation, microbial ecology and ruminant production. Asian Journal of Animal and Veterinary Advances, 6: 416-428.

Patra, A.K. and Z. Yu (2012). Effects of essential oils on methane production and fermentation by, and abundance and diversity of, rumen microbial populations. Appl. Environ. Microbiol., 78:42714280.doi:10.1128/AEM.00309-12.

Rezaei, N. and H.A. Pour (2012). Evaluation effect of thyme extract on degradability of soybean meal with gas product technique. Advances in Bioresearch, 3: 45-47. 
Russell, J.B., H.J. Strobel and G. Chen (1988). Enrichment and isolation of a ruminal bacterium with a very high specific activity of ammonia production. App. Environ. Microbiol., 54: 872-877.

Sivropoulou, A., E. Papanikolaou, C. Nikolaou, S. Kokkini, T. Lanaras and M. Arsenakis (1996). Antimicrobial and cytotoxic activities of Origanum essential oils. J. Agric. Food Chem., 44: 12021205.

Statistical Analysis System SAS (2009). SAS/STAT User's guide, Version 9.2. Cary, NC: SAS Institute Inc.

Tekippe, J.A., A.N. Hristov, K.S. Heyler, T.W. Cassidy, V.D. Zheljazkov and J.F. Ferreira (2011). Rumen fermentation and production effects of Origanum vulgare L. leaves in lactating dairy cows. J Dairy Sci., 94: 5065-5079. https://doi.org/10.3168/jds.2010-4095 PMID: 21943758.

Van Soest, P.J., J.B. Robertson and B.A. Lewis (1991). Methods for dietary fiber, neutral detergent fiber and nonstarch polysaccharides in relation to animal nutrition. J. Dairy Sci., 74: 3583-3597.

Wallace, R.J. (2004). Antimicrobial properties of plant secondary metabolites. Proceedings of the Nutrition Society, v.63, p.621-629.

Wallace, R.J., N.R. McEwan, F.M. McIntosh, B. Teferedegne and C.J. Newbold (2002). Natural products as manipulators of rumen fermentation. Asian-australas. J. Anim. Sci., 15:10-21.

Walsh, S.E., J.Y. Maillard, A.D. Russell, C.E. Catrenich, D.L. Charbonneau and R.G. Bartolo (2003). Activity and mechanisms of action of selected biocidal agents on gram-positive and -negative bacteria. J. Appl. Microbiol., 94:240-

\footnotetext{
تأثير اضافة الزيوت العطرية للبردقوش او الريحان للعلائق على عملية الهضم وتخمرات الكرش وانتاج الغاز الكلي معمليا

نادية احمد حسين سليم'، احمد محمود عبد التواب1، عبد القادر محمود خليف1، حمدى عحمد السيد²، نصرالسيد البردينى2،

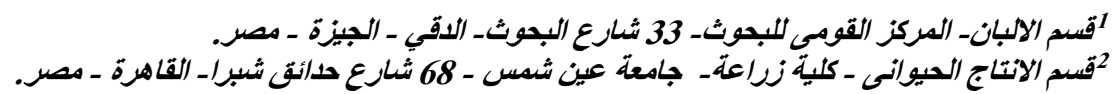

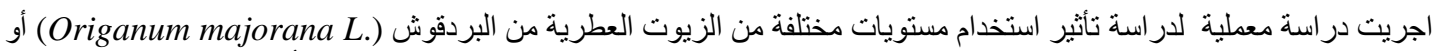

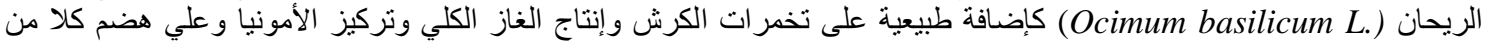

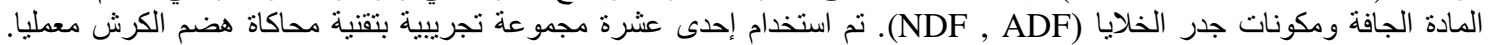

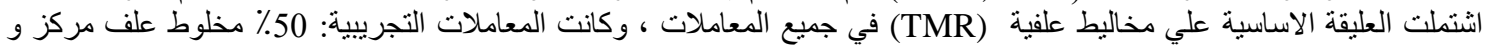

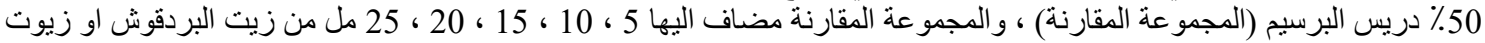

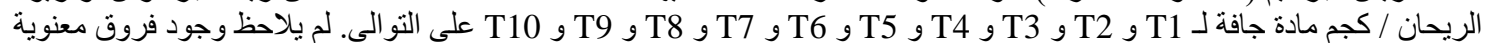

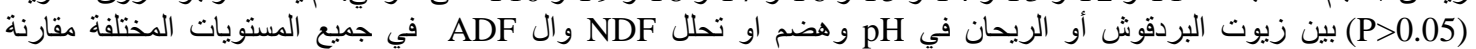

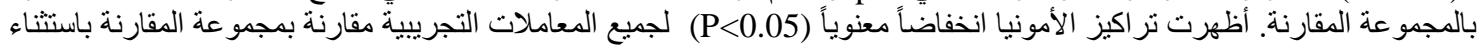

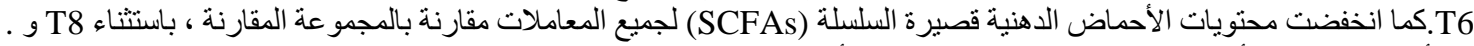

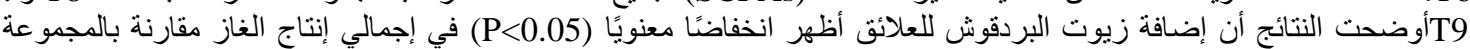

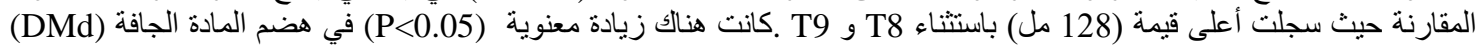

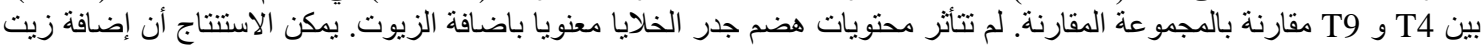

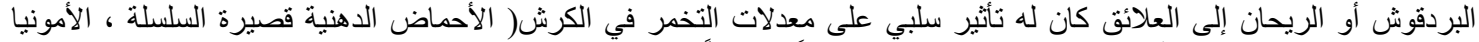

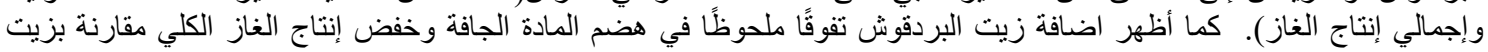
الريحان.
} 